\title{
Analyzing the Relationship between Positive Psychological Capital and Organizational Commitment of the Teachers
}

\author{
Sinan YALCIN ${ }^{1}$ \\ ${ }^{1}$ Faculty of Education Department of Educational Sciences, University of Erzincan, Turkey \\ Correspondence: Sinan YALCIN, Faculty of Education Department of Educational Sciences, University of \\ Erzincan, Turkey. E-mail: sinan29@gmail.com
}

Received: April 28, 2016

Accepted: May 30, $2016 \quad$ Online Published: July 26, 2016

doi:10.5539/ies.v9n8p75

URL: http://dx.doi.org/10.5539/ies.v9n8p75

\begin{abstract}
In this study it was aimed to determine the relationship between teachers' positive psychological capital levels and organisational commitment. The study was conducted as a correlational survey which is one of the quantitative methods. The sample group consists of 244 teachers selected by using random sampling method among 1270 teachers working in primary, elementary and high schools in Erzincan city center in 2015-2016 academic year. The data was collected with Positive Psychological Capital Scale and Organisational Commitment Scale. The data was analysed by using correlation and regression analyses. The findings show that there was a significant positive relationship between the teachers' positive psychological capital levels and organizational commitment in terms of both total scores and sub-dimensions.
\end{abstract}

Keywords: psychological capital, positive psychological capital, organizational commitment, teacher

\section{Introduction}

The fact that human is the most important source to carry out organisational objectives in today. This reality has been directed organisational managements to the new pursuits on human resources. It is a desired and welcomed situation that the human resource in an organisation should be motivated in the direction of the organisational objectives and performed in this direction. Organisational managements apply various methods to increase the performances of the employees. One of these applications can to increase the psychological capital of the employees.

The psychological capital term is stated as the most recently used term within an organisation today (Akdoğan \& Polatc1, 2013). Psychological capital is a factor increasing the performance of the employees in the organization. It is also a strong management tool which provides a performance increasing on the employees and contributes the organisational assets (Luthans et al., 2005).

As a sub-system within an education system the function of the school is considered to achieve objectives and respond to the social demands. For this purpose, a set of activities like educational and management activities are conducted. For this purpose the schools need individuals who are motivated to achieve their objectives and who are highly identified with their schools. To reach school objectives, the school employees should have high organizational commitment level (Balay, 2000; Buluç, 2009). The commitment of the employees to the organization and the institution they work would contribute to them to adopt, to embrace and internalize their organizations. Considering in this respect, organizational commitment will ensure that the employees become integrated with the organization, and it will provide that the organization is a livable place for the employees.

The role of the school within social structure is quite important. To reach the formal structure called school to its objectives, the importance of the school managers and the teachers are considerably big. The fact that the school manager and the teachers are bond with the school and their work at heart in school life, they have higher job satisfaction, they communicate effectively with the students, parents and other teachers, that is, the shareholders of the school can be considered to be the basic necessity for a school to achieve its objectives (Erdem, 2010). Based upon these approaches, we can say that the effect of the commitment of the school managers and the teachers on their performance, job satisfaction, organizational climate and success would be undeniable. 


\section{Positive Psychological Capital}

Among the affecting factors the individuals behaviors in their work life are the characteristics of the individuals and the quality of the work, job environment and job specifications, besides those, emotional life of the employees also takes up a lot of room. Psychological and emotional changes of the employees in work life affect the work life of the employees and their motivation for work. In this sense, the emotional features of the employees and their experiences in the job environment have effects on their work life and their commitment to the organization they work (Özdevecioğlu, 2004).

Psychological capital can be defined as a whole of features which can be improved with experience or education in particularly increasing the performance of the employee in work life and improving organizational performance (Luthans, 2002). In this context, positive psychology and positive organizational behavior will contribute more to the organization on condition that the positive psychological capital levels of the employees in the work life are higher (Erkuş \& Findıklı, 2013).

Positive psychology is that the individuals focus on their strong aspects rather than their problematic aspects. In this direction, positive psychology contributes to the organizations in defining characteristics that make the individuals more positive (Erkmen \& Esen, 2012).

It is suggested that the psychological features explain ideally the psychological capital that these features are hope, psychological durability, optimism and self-sufficiency (Luthans, 2002). In the scale developed by Tösten and Özgan (2014), hope, psychological durability, optimism, self-sufficiency, confidence and extroversion features of the scale were dealt with.

In studies abroad conducted about the psychological capital, it were emphasized on the relationship between psychological capital and "occupational stress", "burnout and participation of the employees" (Herbert, 2011), "human and society" (Luthans \& Youssef, 2004), "adaptation and behavior" (Larson et al., 2013), "teaching activity in primary schools" (Wang et al., 2014), "collective self-respect of the teachers" (Bissessar, 2014), "leadership and creative performance behaviors" (Gupta, 2012), "mid-level manager roles" (Madden, 2013), "leadership development" (Ruderman \& Clerkin, 2015), "innovation and creativity" (Morsy, 2015), "life satisfaction and success" (Ganiron, 2012), "working and being good" (Cole, 2007) were emphasized.

In the Turkey studies, the relationship between psychological capital and "organizational citizenship behavior" (Berberoğlu, 2013); “job satisfaction" (Akçay, 2011); "organizational commitment” (Çınar, 2011); "task performance" (Polatc1, 2011); "occupational commitment" (Kaya, 2012); "the role of trust in organization in the relationship between resistance to change and communication" (Saruhan, 2013); "work life" (Araz, 2013); "psychological capital perceptions of the teachers" (Tösten, 2015); "job satisfaction” (Kaplan \& Biçkes, 2013); "emotional labor and job satisfaction" (Biçkes et al., 2014); "authentic leadership" (Keser \& Kocabaş, 2014); "supportive organizational climate" (Çetin et al., 2013); "duty and contextual performance" (Polatc1, 2014); "job satisfaction and organizational commitment" (Çetin \& Basım, 2011); "emotional labor and alienation to work" (Tokmak, 2014) were analyzed.

\section{Organizational Commitment}

The organizational commitment is considered today as one of the most important subjects in providing success. Organizational commitment is an important term for an organization aiming to be effective and productive. Organizational commitment can be considered as the effort of an organization to preserve its presence in the social structure.

The organizational commitment term is defined as the identification and integration level and the feelings of an individual about an organization (Sağlam-Arı, 2003). The psychological commitment of an individual include participation the work, loyalty and beliefs to the organization values (Ölçüm-Çetin, 2004, p. 90). Because, employees with high organizational commitment in an organization conduct their duties in harmony with other employees, with high job satisfaction, more productive, with higher commitment and responsibility (Balc1, 2003).

High commitment level of the teachers to school objectives is one of the most important factors to achieve the school its objectives. The desire keeping at the job, the commitment, working with enthusiasm, job satisfaction, work life quality, motivation, etc. of the teachers increase the school commitment.

One of the most important problems of the education system is that the enthusiasm and commitment of the teachers towards their work get lower and lower. The reason of this situation can be stemmed from the problems in the social, psychological and physiological life and the problems within organizational structure. The lower organizational commitment of teachers can be listed among these reasons. It can be said that the high 
concordance between the teachers' personal values and organizational values are produced the higher performances by teachers (Özkan, 2008).

In various studies carried out about the organizational commitment of the employees, it was determined that the employees with higher organizational commitment display more performance.

It can be stated that increasing the organizational commitment is related to the factors such as performance, motivation, commitment to the organization, job satisfaction of the employees. Consequently, the psychological and emotional aspects of the employees should be improved, professional development opportunities should be increased, their abilities and personal characteristics should be developed (Uğurlu-Kara, 2014).

\section{Method}

As it was aimed in this study to determine the relationships between the positive psychological capital levels and organizational commitment of the teachers, correlational research design was used. Correlational research is defined as "a research model which aims to determine the correlations between two or more variables (Karasar, 2012).

\subsection{Participants}

The study group consists of 244 teachers. The study group was determined by using random sampling method among 1270 teachers working in primary, elementary and high schools in Erzincan city center in 2014-2015 academic year. $126(51.6 \%)$ teachers were males, and 118 (48.4\%) teachers were females. 129 teachers work in primary school, 77 teachers work in primary schools, and 38 teachers work in high schools. 205 teachers were married, and 39 teachers were single. 48 teachers have 1-5 year job seniority, 65 teachers have 6-10 year, 33 teacher have 16-20 year, and 45 teacher have 21 and more year job seniority.

\subsection{Data Collection Tools and Data Collection}

Positive Psychological Capital Scale and Organizational Commitment Scale were used as the data collection tools.

\section{Organizational Commitment Scale:}

Organizational Commitment Scale developed by Balay (2000), and consists of 27 items. The Organizational Commitment Scale has included three sub-dimensions. The sub-dimensions are (1) adaptation, (2) identification, and (3) internalization. Each dimension was considered as a subscale. The reliability co-efficient for adaptation sub-dimension was $\alpha=.68, \alpha=.80$ for identification sub-dimension and $\alpha=.90$ for internationalization sub-dimension. Cronbach Alpha co-efficient of Organizational Commitment cale was determined as $\alpha=.77$.

Positive Psychological Capital Scale:

Positive Psychological Capital Scale developed by Tösten and Özgan (2014) consist of six dimensions namely; self-sufficiency, optimism, extroversion, psychological durability, and hope. Positive psychological capital scale consists of 26 items. Reliability analsis was conducted by Tösten and Özgan (2014). Cronbach's Alpha values were calculated as .80 for self-sufficiency, .80 for optimism, .83 for confidence, .79 for extroversion, .76 for psychological durability, .73 for hope, and respectively sub-dimension as .93 . In analyses for this study, the Cronbach's Alpha values were determined as .74 for self-sufficiency, .86 for optimism, .69 for confidence, .80 for extroversion, .83 for psychological durability, .81 for hope, and respectively as .92 .

\subsection{Data Analysis}

Before analyzing, the data was reviewed in terms of missing values, extreme values, normality, multivariate; the forms left one or more scores are blank were not included in the evaluation. 244 forms were included in the evaluation. SPSS was used for data analyses. The correlation and regression analysis were conducted.

\section{Findings and Results}

In Table 1 the regression analysis on positive psychological capital levels and teachers' organizational commitment is seen. 
Table 1. The regression analysis on positive psychological capital levels and teachers' organizational commitment

\begin{tabular}{|c|c|c|c|c|c|c|c|c|c|c|c|}
\hline & & 1 & 2 & 3 & 4 & 5 & 6 & 7 & 8 & 9 & 10 \\
\hline 1 & Adaptation & 1 & & & & & & & & & \\
\hline 2 & Identification & $.228 * *$ & 1 & & & & & & & & \\
\hline 3 & Internalization & $.340 * *$ & $.346^{* *}$ & 1 & & & & & & & \\
\hline 4 & Commitment Tot. & -.039 & $.789 * *$ & $.826^{* *}$ & 1 & & & & & & \\
\hline 5 & Self-sufficiency & $.127^{*}$ & $.223 * *$ & $.342 * *$ & $.262 * *$ & 1 & & & & & \\
\hline 6 & Optimism & .114 & $.243 * *$ & $.257 * *$ & $.464 * *$ & $.403 * *$ & 1 & & & & \\
\hline 7 & Confidence & $.232 * *$ & $.139 *$ & $.379 * *$ & $.235^{* *}$ & $.536 * *$ & $.408^{* *}$ & 1 & & & \\
\hline 8 & Extraversion & $.225^{* *}$ & $.346^{* *}$ & $.498 * *$ & $.424 * *$ & $.342 * *$ & $.257^{* *}$ & $.558 * *$ & 1 & & \\
\hline 9 & P. Duration & $.220 * *$ & $.375 * *$ & $.724 * *$ & $.452 * *$ & $.402 * *$ & $.724 * *$ & $.579 * *$ & .724 & 1 & \\
\hline 10 & Hope & $.244 * *$ & $.269 * *$ & $.546^{* *}$ & $.295 * *$ & $.330^{* *}$ & $.272 * *$ & $.511^{* *}$ & $.546^{* *}$ & $.739 * *$ & 1 \\
\hline 11 & P.Capitaltot. & $.25 * *$ & $.373 * *$ & $.51 * *$ & $.44 * *$ & $.65 * *$ &. $.78 * *$ & $.77 * *$ & $.78 * *$ & $.85 * *$ & $.73 * *$ \\
\hline
\end{tabular}

In Table 1 , it is seen that there is a positive significant relationship among the adaptation $(\mathrm{r}=.25, \mathrm{p}<.01)$, identification $(\mathrm{r}=.37, \mathrm{p}<.01)$, and internalization $(\mathrm{r}=.51, \mathrm{p}<.01)$ sub-dimensions.

There is no significant relationship between adaptation dimension and optimism dimension $(r=.11, p>.01)$, there is a positive significant relationship among the self-sufficiency $(\mathrm{r}=13, \mathrm{p}<.05)$, confidence $(\mathrm{r}=.23, \mathrm{p}<.01)$, extraversion $(\mathrm{r}=.23, \mathrm{p}<.01)$, psychological duration $(\mathrm{r}=.22, \mathrm{p}<.01)$ and hope $(\mathrm{r}=.24, \mathrm{p}<.01)$ dimensions. It can be said that There is a positive significant relationship among the identification sub-dimension and self-sufficiency $(\mathrm{r}=.22, \mathrm{p}<.01)$, optimism $(\mathrm{r}=.24, \mathrm{p}<.01)$, confidence $(\mathrm{r}=.14, \mathrm{p}<.05)$, extraversion $(\mathrm{r}=.35, \mathrm{p}<.01)$, psychological durability $(\mathrm{r}=.38, \mathrm{p}<.01)$, and hope $(\mathrm{r}=.27, \mathrm{p}<.01)$ sub-dimensions.

There is a positive significant relationship among the internalization sub-dimension and self-sufficiency $(\mathrm{r}=.34$, $\mathrm{p}<.01)$, optimism $(\mathrm{r}=.26, \mathrm{p}<.01)$, confidence $(\mathrm{r}=.38, \mathrm{p}<.05)$, extraversion $(\mathrm{r}=.50, \mathrm{p}<.01)$, psychological durability $[\mathrm{r}=.72, \mathrm{p}<.01]$ and hope $(\mathrm{r}=.55, \mathrm{p}<.01)$ sub-.

When total scores are evaluated, it is seen that there is a positive significant relationship between organizational commitment and positive psychological capital $[\mathrm{r}=.44, \mathrm{p}<.01]$.

Table 2. Regression analysis results $(\mathrm{N}=244)$

\begin{tabular}{llllll}
\hline Hope & $\mathrm{B}$ & $\mathrm{SH}_{\mathrm{B}}$ & $\beta$ & $\mathrm{t}$ & $\mathrm{p}$ \\
\hline Fixed & 9.504 & 1.389 & - & 27.770 & 0.000 \\
Self-sufficiency & -.04 & .20 &,- 01 &, 379 & .857 \\
Optimism & .03 & .11 &, 017 & $-1,515$ & .815 \\
Confidence & .35 & .26 &, 117 & $-2,039$ & .19 \\
Extraversion & .18 & .17 & .10 & $-2,233$ & .28 \\
Psychological Duration & -.07 & .22 &,- 04 & .68 & .76 \\
Hope & .44 & .26 & .15 & -2.06 & .10 \\
$\mathrm{R}=0,283 \mathrm{R}^{2}=0,080$ & & & & &
\end{tabular}

In Table 2, it is seen that positive psychological capital level explains $8 \%$ of the total variance of hope dimension $\left(\mathrm{R}^{2}=.080\right)$. According to the standardized regression coefficient $(\beta)$, it is seen that the importance of predictive variables on the hope sub-dimension is ranked as hope, confidence, extraversion, psychological durability, optimism and self-sufficiency. 
Table 3. Regression analysis results $(\mathrm{N}=244)$

\begin{tabular}{llllll}
\hline Identification & $\mathrm{B}$ & $\mathrm{SH}_{\mathrm{B}}$ & $\beta$ & $\mathrm{t}$ & $\mathrm{p}$ \\
\hline Fixed & 17,303 & 1,526 & - & 11,336 & 0,000 \\
Self-sufficiency &, 375 &, 216 &, 123 & 1,736 &, 084 \\
Optimism &, 482 &, 187 &, 224 & 2,576 &, 011 \\
Confidence &,- 276 &, 254 &,- 079 & $-1,086$ &, 278 \\
Extraversion &, 839 &, 156 &, 391 & 5,375 &, 000 \\
Psychological Duration &, 568 &, 244 &, 251 & 2,323 &, 021 \\
Hope &, 053 &, 292 &, 016 &, 183 &, 855 \\
$\mathrm{R}=0,450 \mathrm{R}^{2}=0,203$ & & & & &
\end{tabular}

On analyzing Table 3, it is seen that the sub-dimensions of positive psychological capital altogether explain $20 \%$ of the total variance of identification dimension $\left(\mathrm{R}^{2}=.20\right)$ of organizational commitment. It can be said that optimism, extraversion and psychological durability sub-dimensions are significant predictors of identification sub-dimension of organizational commitment. The order of importance of the predictive variables on the identification sub-dimension of organizational commitment is extraversion, psychological durability, optimism, self-sufficiency, confidence and hope.

Table 4. Regression analysis results related to the prediction level of positive psychological capital levels of the teachers for internalization sub-dimension of organizational commitment

\begin{tabular}{llllll}
\hline Internalization & $\mathrm{B}$ & $\mathrm{SH}_{\mathrm{B}}$ & $\beta$ & $\mathrm{t}$ & $\mathrm{p}$ \\
\hline Fixed & 8,763 & 1,830 & & 4,788 &, 000 \\
Self-sufficiency &, 218 &, 259 &, 056 &, 840 &, 402 \\
Optimism &, 712 &, 224 &, 259 & 3,173 &, 002 \\
Confidence &, 657 &, 298 &, 147 & 2,202 &, 029 \\
Extraversion & 1,144 &, 183 &, 416 & 6,244 &, 000 \\
Psychological Duration &, 767 &, 293 &, 265 & 2,616 &, 009 \\
Hope &,- 020 &, 350 &,- 005 &,- 058 &, 954 \\
$\mathrm{R}=0,547 \mathrm{R}^{2}=0,299$ & & & & & \\
\hline
\end{tabular}

In Table 4, it is seen that the sub-dimensions of positive psychological capital altogether explain $30 \%$ of the total variance of internalization dimension $\left(\mathrm{R}^{2}=.30\right)$. The importance of the predictive variables on the internalization sub-dimension is ranked as the extraversion, psychological durability, optimism, confidence, self-sufficiency, and hope.

\section{Discussions and Conclusion}

Human resource has an important place in achieving the organizational goals. The factors such as the employees have high motivation levels, their commitment to their job, the quality of their work life, they are satisfied with the work they do, they have positive psychological and emotional life in the workplace, etc. are considered to be important factors to increase the productivity of the employees and make the organization successful by making it effective. In the schools whose importance and role is highly greater in the social structure, it is expected that the commitment of the teachers are high. Many factors can be referred in terms of increasing the commitment of the teachers to the school. One of these factors is positive psychological capital.

In this study the relationship between the positive psychological capital levels and teachers' organizational commitment were analyzed. The results are discussed below.

There is a significant relationship between the positive psychological capital levels and organizational commitment of the teachers. According to this result, it can be said that the reason why the organizational commitment of the teachers is high is that their positive psychological capital levels are high. This result 
obtained from the study is parallel with the results of the studies conducted formerly.

In the previous studies conducted by Çetin (2011) and Peng et al. (2013), it was determined that psychological capital affects organizational commitment positively. In another study by Shahnawaz and Jafri (2009), it was stated that psychological capital effect private and public institutions in terms of organizational commitment. In the study conducted by Çoban (2013), it was determined that psychological capital has a complete mediation effect on interactional justice and organizational commitment.

In a study conducted by Genç (2014), it was determined that psychological durability affects organizational commitment in a positive way. Similarly, in a study conducted by Murray et al. (2010), it was determined that there is a positive relationship between psychological capital and organizational commitment. Hodges (2010) determined in his study that psychological capital has a positive effect on the commitment of the employees. In a study conducted by Çetin (2011) positive psychological capital support the organizational commitment in hope and optimism sub-dimensions. Luthans et al. (2008) determined that there is a positive relationship between the psychological capital and organizational commitment. In the study conducted by Simons and Buitendach (2013), it was stated that there is a positive and significant relationship between psychological capital and organizational commitment. Moreover, it was determined that there is a positive significant relationship between the sub-dimensions of psychological capital and organizational commitment. In study conducted by McColl-Kennedy and Anderson (2005), it was stated that there is a positive relationship between the optimism sub-dimension of the psychological capital and organizational commitment. Saks (2006) determined in his study that there is significant relationship between self-sufficiency and organizational commitment. In the study conducted by Avey et al. (2008), it was concluded that the psychological capital of the employees affects their commitment.

It was determined that there is a positive significant relationship among the adaptation sub-dimension and self-sufficiency, confidence, extraversion, psychological durability and hope sub-dimensions of positive psychological capital. It can be said that if the characteristics of the teachers including being able to motivate themselves, having a set of capabilities to fulfil the tasks, being enthusiastic and showing the required effort in reaching the objectives, enduring the difficult and uncertain conditions, having higher self-confidence are increased, they display more positive behaviors in school.

There is a positive significant relationship among the identification sub-dimension and the self-sufficiency, optimism, confidence, extraversion, psychological duration and hope sub-dimensions. It can be stated that there is a positive significant relationship among the identification sub-dimension and the self-sufficiency, optimism, confidence, extraversion, psychological duration, and hope sub-dimensions. According to this result, it can be said that the teachers have the desiring to accomplish individual and organizational objectives, having the ability to fulfil a task in the best way she/he realizing his/her skills, being able to show the optimistic perspective against the events occurring within organizational life, being able to show strong and positive social behaviors in social and school life, trusting other teachers within the school and perceiving as a trustworthy human by others makes the teachers to integrate their values with the values of the school and internalizing the school more.

It was seen that the positive psychological capital is a significant predictor of organizational commitment. It was determined that the sub-dimensions of positive psychological capital are not significant predictors of the adaptation sub-dimension of organizational commitment. It can be stated that the optimism, extraversion and psychological durability sub-dimensions are the significant predictors of the identification sub-dimension. The optimism, confidence, extraversion and psychological durability sub-dimensions of positive psychological capital are significant predictors of internalization sub-dimension.

In a study conducted by Shahnawaz and Jafri (2009), it was determined that psychological capital explains about $6 \%$ of organizational commitment. In the study conducted by Simons and Buitendach (2013), it was stated that psychological capital is a significant predictor of organizational commitment. In another study conducted by Çoban (2013), it was determined that psychological capital has a partial mediation role in the relationship between procedural justice and organizational commitment, and psychological capital has a complete mediation role in the relationship between interactional justice and organizational commitment. As a result, it can be said that the positive psychological capital levels of the teachers are an important factor in explaining and increasing the organizational commitment of the teachers in terms of both total scores and sub-dimensions.

\section{Recommendations}

In this study, the relationship between positive psychological capital and organizational commitment was analyzed. The study can be conducted on different occupational groups. Further researches can be conducted on the relationship between positive psychological capital and other variables such as satisfaction, motivation, work 
life quality, job satisfaction. This study was conducted in public institutions. The same study can be conducted in public and private institutions comparatively. Training activities can be organized for the school managers about how to improve the positive psychological capital levels of the teachers. It can be analyzed that how various variables affect the positive psychological capital levels and organizational commitment of the teachers.

\section{References}

Akçay, V. H. (2011). The effect of job satisfaction in terms of personal values of positive psychological capital and research (Unpublished doctoral dissertation). İstanbul University Social Sciences Institute. İstanbul.

Akdoğan, A., \& Polatc1, S. (2013). The role of work family spillover and psychological well-being on the effect of psychological capital on performance. Ataturk University Institute of Social Sciences Journal, 17(1).

Araz, Y. (2013). Contextual analysis of the effects of positive psychological capital's on business life (Master's thesis, Zirve University Institute of Social Sciences, Gaziantep)

Avey, J. B., Wernsing, T. S., \& Luthans, F. (2008). Can positive employees help positive organizational change? Impact of psychological capital and emotions on relevant attitudes and behaviors. The Journal of Applied Behavioral Science, 44(1), 48-70. http://dx.doi.org/10.1177/0021886307311470

Balay, R. (2000). Private and public school administrators and organizational commitment of teachers (Unpublished $\mathrm{PhD}$ thesis). Ankara University Institute of Social Sciences Education, Ankara.

Balc1, A. (2003). Organizational socialization theory, strategy and tactics. Ankara: Pegem Publishing.

Berberoğlu, N. (2013). The impact of psychological capital on organizational citizenship behavior: A field study (Unpublished Master's thesis). Gazi University Social Sciences Institute. Ankara.

Biçkes, D. M., Yılmaz, C., Demirtaş, Ö., \& Uğur, A (2014). The Role of Psychological Capital Brokerage Relationship Between Job Satisfaction and Emotional Labor: A Case Study. Eskişehir Osmangazi University Journal of Economics and Administrative Sciences, 9(2).

Bissessar, C. S. (2014). An exploration of the relationship between teachers' psychological capital and their collective self-esteem. Australian Journal of Teacher Education (Online), 39(9). http://dx.doi.org/10.14221/ajte.2014v39n9.4

Buluç, B. (2009). The Relationships between Organizational Commitment and Leadership Styles of Principals Based on Elementary School Teacher's Perceptions. Educational Administration: Theory and Practice, 15(57).

Cole, K. (2007). Good for the Soul: The Relationship between Work, Wellbeing, and Psychological Capital (Ph.D. in Economics at the University of Canberra).

Çetin, F. (2011). The effects of the organizational psychological capital on the attitudes of commitment and satisfaction: A public sample in Turkey. European Journal of Social Sciences, 21(3).

Çetin, F., \& Basım, H. N. (2011). The Role of Job Satisfaction and Organizational Commitment of Resilience. The Journal of Industrial Relations \& Human Resources, 13(3). http://dx.doi.org/10.4026/1303-2860.2011.0184.x

Çetin, F., Hazır, K., \& Basım, H. N. (2013). The Interaction between Supportive Organizational Culture and Psychological Capital: The Mediating Role of Locus of Control. Hacettepe University Journal of Economics and Administrative Sciences, 31(1).

Çınar, E. (2011). Organizational commitment relationship of positive psychological capital (Unpublished master's thesis). Dokuz Eylül University Institute of Social Sciences.

Çoban, A. (2013). Psychological capıtal organızatıonal justıce and organızatıonal role on the commıtment relations. Journal of Organization and Management Sciences, 5(2).

Erdem, M. (2010). Quality of Work Life and Its Relation to Organizational Commitment According to Teachers in Secondary Schools. Educational Administration: Theory and Practice, 16(4).

Erkmen, T., \& Esen, E. (2012). A research about determinıng employees' psychological capital level in information sector. Afyon Kocatepe University, Economics And Administrative Sciences Journal Journal, 14(2).

Erkuş, A., \& Findıkl1, M. (2013). A research on the impact of psychological capital to job satisfaction, job performance and intention to quit. Istanbul University Journal of the School of Business, 42(2). 
Genç, A. (2014). Organizational commitment and intention to leave, the psychological impact resistance: An empirical study (Doctoral dissertation). Başkent University, Social Sciences Institute. Ankara

Gupta, V., \& Singh, S. (2014). Psychological capital as a mediator of the relationship between leadership and creative performance behaviors: Empirical evidence from the Indian R\&D sector. The International Journal of Human Resource Management, 25(10). http://dx.doi.org/10.1080/09585192.2013.870311

Herbert, M. (2011). An exploration of the relationships between psychological capital (hope, optimism, self-efficacy, resilience), occupational stress, burnout and employee engagement (Unpublished master's thesis). University of Stellenbosch, South Africa.

Hodges, T. D. (2010). An experimental study of the impact of psychological capital on performance, engagement, and the contagion effect (Dissertations and Theses from the College of Business Administration).

Kaplan, M., \& Biçkes, D. M. (2013). The Relationship Between Psychological Capital and Job Satisfaction. Management and Economy, 20(2).

Karasar, N. (2012). Scientific research method (24th ed.). Nobel broadcast distribution. Ankara.

Kaya, Ş. D. (2012). A model proposal for determining the effects of career planning and professional commitment to the relationship of psychological capital (Unpublished doctoral dissertation). Selçuk University Social Sciences Institute.

Keser, S., \& Kocabaş, İ. (2014). The comparison of elementary school administrators' authentic leadership and psychological capital features. Educational Administration: Theory and Practice, 1(1).

Larson, M. D., Norman, S. M., Hughes, L. W., \& Avey, J. B. (2013). Psychological capital: A new lens for understanding employee fit and attitudes. International Journal of Leadership Studies, 8(1).

Luthans, F. (2002). Positive Organizational Behavior: Developing and Managing Psychological Strengths. Academy of Management Executive, 16(1). http://dx.doi.org/10.5465/AME.2002.6640181

Luthans, F., \& Youssef, C. M. (2004). Human, social, and now positive psychological capital management: Investing in people for competitive advantage. Organizational dynamics, $33(2)$. http://dx.doi.org/10.1016/j.orgdyn.2004.01.003

Luthans, F., Avolio, B. J., Walumbwa, F. O., \& Li, W. (2005). The Psychological Capital of Chinese Workers: Exploring the Relationship with Performance. Management and Organization Review, 1(2). http://dx.doi.org/10.1111/j.1740-8784.2005.00011.x

Luthans, F., Norman, S. M., Avolio, B. J., \& Avey, J. B. (2008). The mediating role of psychological capital in the supportive organizational climate-employee performance relationship. Journal of Organizational Behavior, 29. http://dx.doi.org/10.1002/job.507

Madden, L. T. (2013). Juggling demands: The Impact of Middle Manager roles and Psychological Capital (PhD diss., University of Tennessee).

McColl-Kennedy, J. R., \& Anderson, R. D. (2005). Subordinate-manager gender combination and perceived leadership style influence on emotions, self-esteem and organizational commitment. Journal of Business Research, 58(2). http://dx.doi.org/10.1016/S0148-2963(03)00112-7

McMurray, A. J., Pirola-Merlo, A., Sarros, J. C., \& Islam, M. M. (2010). Leadership, climate, psychological capital, commitment, and wellbeing in a non-profit organization. Leadership \& Organization Development Journal, 31(5). http://dx.doi.org/10.1108/01437731011056452

Morsy, S. M., \& Yomna, M. (2015). Innovation, Creativity, and Positive Psychological Capital: Examining the Relationships in Adolescents, Employees and Entrepreneurs (Doctoral dissertation, Kassel, Univ., Diss., 2014).

Ölçüm-Çetin. M. (2004). Organizational culture and organizational commitment. Nobel publications. Ankara.

Özdevecioğlu, M. (2003). Perceived organizational support with a study to determine the relationship between organizational commitment. Dokuz Eylul University Journal of economics and administrative sciences, $18(2)$.

Özkan, V. (2008). According to some variable organizational commitment levels of primary school teachers in charge (Master's thesis, Sakarya University, Institute of Social Sciences, Sakarya).

Peng, J., Jiang, X., Zhang, J., Xiao, R., Song, Y., Feng, X., . . Miao, D. (2013). The impact of psychological capital on job burnout of Chinese nurses: the mediator role of organizational commitment. PloS one, $8(12)$. 
http://dx.doi.org/10.1371/journal.pone.0084193

Polatci, S. (2014). The Effects of Psychological Capital on Task and Contextual Performance: A Research on Police Organization. Ege Academic Perspective Journal, 14(1).

Polatç1, S. (2011). The role of work famlly spillover and psychological well-being on the effect of psychological capital on performance (Unpublished doctoral dissertation). Erciyes University Social Sciences Institute. Kayseri.

Rowe, K. P. (2013). Psychological capital and employee loyalty: The mediating role of protean career orientation. University of Canterbury

Ruderman, M. N., \& Clerkin, C. (2015). Developing Leadership by Building Psychological Capital. Research Report.

Sağlam-Arı, G. (2003). Does the trust for the manager increase organizational commitment. Gazi University Journal of Commerce and Tourism Education, 2.

Saks, A. M. (2006). Antecedents and consequences of employee engagement. Journal of Managerial Psychology, 21(7). http://dx.doi.org/10.1108/02683940610690169

Saruhan, N. (2013). İletişimin kuruma güven aracıllğıyla değişime direnç ile olan ilişkisinde psikolojik sermaye ve algılanan kurumsal adaletin şartlı değişken rolü (Unpublished doctoral dissertation, Marmara University, Social Sciences Institute).

Shahnawaz, M. G., \& Jafri, M. H. (2009). Psychological capital as predictors of organizational commitment and organizational citizenship behaviour. Journal of the Indian Academy of Applied Psychology, 35.

Simons, J. C., \& Buitendach, J. H. (2013). Psychological capital, work engagement and organisational commitment amongst call centre employees in South Africa. SA Journal of Industrial Psychology, 39(2). http://dx.doi.org/10.4102/sajip.v39i2.1071

Tokmak, İ. (2014). The Moderating Effect of Psychological Capital in the Relation Between Emotional Labor And Work Alienation. Journal of Business Research-Türk, 6/3. http://dx.doi.org/10.20491/isader.2014315943

Tösten, R. (2015). Examination of teachers' perceptıons on posittve psychological capttal (Ph.D. thesis, Gaziantep University Education Science İnstitute. Gaziantep).

Tösten, R., \& Özgan, H. (2014). The Scale of Positive Psychological Capital: A Reliability and Validity Study. EKEV Journal of the Academy, 59.

Ucol-Ganiron Jr, T. (2012). The additive value of psychological capital in predicting structural project success and life satisfaction of structural engineers. International Journal of Social Science and Humanity, 2(4).

Uğurlu-Kara, A. (2014). The relationship between individual performance positive psychological capital (Master's Thesis, Gazi University Institute of Social Sciences, Ankara).

Wang, J. H., Chen, Y. T., \& Hsu, M. H. (2014). A Case Study on Psychological Capital and Teaching Effectiveness in Elementary Schools. International Journal of Engineering and Technology, 6(4), 331-337. http://dx.doi.org/10.7763/IJET.2014.V6.722

\section{Copyrights}

Copyright for this article is retained by the author(s), with first publication rights granted to the journal.

This is an open-access article distributed under the terms and conditions of the Creative Commons Attribution license (http://creativecommons.org/licenses/by/4.0/). 